\title{
Building the Organizational Leader Brand: Change Agent, Scholar, Thought Leader
}

\author{
Barbara Holmes ${ }^{1}$, Christopher Hahn ${ }^{2} \&$ Carson Perry $^{2}$ \\ ${ }^{1}$ Associate Professor, Education Department, Winona State University, Winona, USA \\ ${ }^{2}$ Graduate Student, Education Leadership, Winona State University, Winona, USA \\ Correspondence: Christopher Hahn, Graduate Student, Education Leadership, Winona State University, Winona, \\ MN 55987, USA.
}

Received: April 25, 2017

Accepted: May 17, 2017

Online Published: May 26, 2017

doi:10.5430/irhe.v2n2p45

URL: https://doi.org/10.5430/irhe.v2n2p45

\begin{abstract}
Who we are matters. Developing the personal brand communicates to the world the values that fuel daily leadership habits and practices. Exposure to branding is constant in everyday life. People are continuously exposed to various brands, including clothing, vehicles, food selection, recreation, and media. Building the organizational leader brand requires the same processes, strategies, and tactics as branding and promoting traditional products, yet is much more involved.

Research supports that millennial audiences connect best with individuals, rather than organizations. Consequently, effective personal branding is essential to building trust and a reputation that supports such viable relationships within organizations. Successful brands are constructed to embody traits the target market or followers identify with, and thus develop an affinity to. Likewise, organizational leadership brands must incorporate the personal traits of the leader into its identity making them unique, compelling and approachable to stakeholders.
\end{abstract}

Keywords: organizational leader brand, leadership identity, personal branding, leadership brand development, stakeholder engagement, millennials, behaviors, personal traits, leadership habits

"Regardless of age, regardless of position, regardless of the business we happen to be in, all of us need to understand the importance of branding," management consultant Tom Peters writes in "The Brand Called You." "We are CEOs of our own companies: Me Inc. To be in business today, our most important job is to be head marketer for the brand called You."

-Martinuzzi (2014)

\section{Introduction}

Who we are matters. Developing the personal brand communicates to the world the values that fuel daily leadership habits and practices. Williams (2015), writing for Forbes Magazine, posits that a personal brand is essential in authentically communicating who you are. However, many educational leader preparation programs do not offer formal training in branding and marketing the organizational leader. Montoya (2002) captures the essence of the personal brand when he asserts "Personal branding is the powerful, clear, positive idea that comes to mind whenever other people think of you. It is what you stand for-the values, abilities, and actions that others associate with you (p.11)".

Building the organizational leader brand requires the same processes, strategies, and tactics as branding a traditional product. Just as leaders have innate personality traits and organizational makeup (Northouse, 2016), crafting a leadership brand also incorporates traits into its identity that makes it unique and approachable to the stakeholder. Brand exposure is constant in daily life as people are continuously surrounded by brands, from clothing, vehicles, food selection, recreation, and media. Building a brand, however, is much more involved.

Successful brands are constructed to embody traits the target market or followers identify with and develop affinity affiliation. Credentials, quality, consistency, morality, and change (Reis \& Reis, 2002), are essential in crafting a 
viable, successful leadership brand. LeBron James, for example, is his brand. He is not just a man, but an athlete, philanthropist, businessman and NBA Champion (James, 2016). As a result, the "LeBron" brand, is presented to the public as including all of these essential components.

Demers (2016) advises that millennial audiences connect best with individuals, rather than organizations. Consequently, personal branding builds trust and reputation that supports such viable relationships. People want to know what values the leader holds and whether the leader is a principled person with integrity. In the 21 st century, the organizational leader needs a personal brand and should build all actions and interactions with followers around that personal brand. Demers (2016) further explains that personal branding requires the leader to develop a signature image, vision, voice, and personal standards that are recognizable to followers. Therefore, the personal brand should reflect the person you are and the person you are trying to be (Lake, 2016).

Developers of leadership brands are encouraged to implement a strategy similar to that of branding a product or service. These strategies include having clearly defined goals, understanding where they wish to take the brand in the market, creating a path on how to get there, and establishing a methodology for evaluating brand success (Bedburry, 2002). It is also important that the brand itself identify as a person to both leader and stakeholder (Kapferer, 2004). In doing so, the organizational leader brand positions itself as a relationship partner with all stakeholders. This positioning becomes the brand's persona. In the same way that interactions take place in a personal relationship, Fournier (1998) acknowledges that the brand to consumer relationship is also "constituted of a series of repeated exchanges between two parties (p. 346)". Once the organizational leader brand is known and identified by stakeholders, the relationship can be allowed to "evolve in response to these interactions and fluctuations in the contextual environment (Fournier, 1998, p. 346)".

\section{Branding as an Intentional Act}

Branding at its best is thoughtful and intentional. The effective organizational leader cannot afford to have the personal brand develop in an unorganized, haphazard manner and needs to intentionally establish an intentional plan to develop image, vision and follower perception. Hyder (2014) points out that everyone has a personal brand including two-year-olds. The personal brand develops with or without the input of the individual. Therefore, organizational leaders benefit when brand characteristics translate into operational integrity, fairness, human relationships, effective communications and positive organizational outcomes. With every speech, meeting, presentation and organizational transaction, the organizational leader is marketing the personal brand to followers and stakeholders. Research now suggests that success comes from the effectiveness of this personal marketing. Kaputa (2003) advises that leaders should intentionally seek opportunities to become more visible within the organizational brand market and find ways to become more effective communicators externally and internally.

\section{Personal Branding and Career Success}

Saltzman (2015) in his article entitled Why Personal Branding is Essential to Career Success, suggests that the personal brand is essential for career advancement and for positioning yourself as an organizational thought leader. Saltzman further explains that there is a synergistic and dynamic relationship between career success and personal branding that when fully understood, has the potential to launch a person's career to new heights. Therefore, attending to personal branding is essential to building a sustainable career. Followers want to identify with the brand characteristics of the leader and need to rely on these characteristics through the ups and downs of organizational changes.

Smale (2015) counsels that your personal brand is how the world perceives you. Therefore, it is preferable that strong brands be developed rather than accumulate in an unorganized manner that is unpolished and uninteresting. For career success, it stands to reason that the organizational leader benefits from a brand that is polished and interesting. Being polished in appearance and image in essential to the organizational; polished in speech and voice; polished in idea generation, and polished in interpersonal interactions that uplift and empower followers.

Williams (2016) in his article The Basics of Branding, asserts that the personal brand is your promise to the people. Consequently, the leader's brand strategy includes all aspects of delivering the brand messages including what, when, how and where. When the brand message is clear and consistent, followers get a distinct impression of who the leader is and are comfortable signing on as followers. When followers see that the leader is respectful, responsible and fair, workplace equity is assured fostering stronger attachment to the organization. The leader's brand builds the leader's reputation and the reputation positions the leader for a continuum of career success and potential as a change agent. 


\section{How to Build the Organizational Leader Personal Brand}

The literature is rich with various ideas for building the personal brand. This article will focus on the practices for personal branding that align with organizational leaders charged with implementing change and transforming organizations. Some branding practices that may be useful for the organizational leader include:

1. Start thinking of yourself as a brand

2. Understand and be your authentic self (Smale, 2015)

3. Develop visible habits of professionalism

4. Deliver what you promise (Martinuzzi, 2014)

5. Respect and engage followers

6. Build a network of advocates and promoters

7. Position yourself as a thought leader in the profession

8. Develop a signature style when speaking and making presentations

9. Remain a student of the profession

10. Seek opportunities for personal exposure to leave a lasting impression

\section{Leadership Identity: Change Agent, Scholar, Thought Leader}

The organizational leader is expected to lead. To keep the organization current and vital, the leader must remain current in the profession and evidence-based change strategies. These include identifying and involving all stakeholders and sharing a vision around which everyone can coalesce. Leaders must be knowledgeable about how to build the personal brand and align that brand with organizational success.

Franko (2015) outlined The Basic Building Blocks of Leadership Identity:

- Leadership brand. Each of us has a brand, whether we consciously shape it or allow others to do it for us. What are you known for that distinguishes you from the crowd, and are you visible to senior leadership?

- Behaviors. Our self-initiated behaviors communicate a lot about us. Do your self-initiated behaviors reflect assertiveness, decisiveness, and confidence?

- Responses. Our responses to situations and people also say a lot about us. What is your emotional intelligence in handling workplace situations and people around you?

- Presence. Do you dress the part of a leader? What does your physical presence exude? Also, every communication, verbal or written, is an opportunity to showcase how well you organize your thoughts and articulate yourself. Do you sound like a leader?

- Habits. Our small actions, done day in and day out, are also known as habits. Who you are as a person is reflected in who you are as a leader, so it makes sense that your habits have a big stake in your leadership path and ultimate success. With the right habits, you stay on course. With the wrong ones, it's easy to end up off the path.

\section{Building Personal Brand through Social Media}

An important component of personal branding is making oneself visible, searchable, and accessible in the cyber world (Labrecque, Markos, \& Milne, 2011). Social media and professional networking websites allow individuals to be found and to stay connected with not only friends and family, but also, potential employers, customers, or competitors. LinkedIn, ResearchGate, Twitter, and Facebook can be used intentionally to build a robust and recognizable personal brand. If used appropriately, these tools will have significant and lasting effects on the brand. However, becoming more searchable and visible does not come without sacrifice.

Separating personal and professional lives is more difficult thanks to social media. Labrecque, Markos, and Milne (2011) discovered that content placed online both implicitly and explicitly brands the individual poster and social media sites are principal tools for self-branding. Additionally, the study revealed pictures and content are equally as important to the self-brand, regardless of who posted the content. If a friend posts inappropriate content to the organizational leader's page, brand promise and promotion may suffer because of the post. 
It is not uncommon for employers, employees or potential clients to search the Internet and social media for individuals encountered in professional settings. However, social media and Internet searches do not discriminate between personal and professional settings. If "Not Suitable for Work" (NSFW) content exists, it will surface when individuals are searched out in online forums. What the leader does outside of the workplace will arise and can be detrimental to the personal brand. However, when used intentionally and as a tool, social media and the Internet serve as aids in building a successful and well-rounded brand.

Before the Internet, the concept of the world being a small place had credence. The phrase "six degrees of separation" is common in movies and books and Travers and Milgram (1967) conducted a study to explore just how small the world is. Postcards, with predetermined recipients, were given to random people who could only pass the card onto someone they directly knew. Travers and Milgram discovered that the number of intermediaries averaged between 4.4 and 5.7. A 2012 study had similar aims. However, Facebook was used to determine the world has in fact shrunk to only four degrees of separation (Backstrom, Boldi, Rosa, Ugander, \& Vigna, 2012).

The evolution of technology allows people to view organizational leader attributes and accomplishments as well as mistakes and failures. When promoting a personal brand, individuals must be aware of what they are putting into the world, not only about themselves but what others are posting as well, personally and professionally.

Companies and organizations use social media and advertisements to promote brand recognition and gain authority in the industry. A strategy for social media platforms is required to remain competitive in the fast-paced business world (Erdoğmuş \& Çiçek, 2012). When thinking of a person as a brand, utilizing social media to perpetuate a similar agenda makes sense. Patel (2016) created a list of ways to enhance personal brands using social media:

Step 1. Find Appropriate Groups Social media sites allow groups to be created for specific industries or topics. Becoming a member of appropriate groups allows individuals to stay current and communicate with other industry leaders.

Step 2. Consistent Image Names, pictures, and the message you are trying to send should be consistent across social media platforms. Consistency will allow the consumers ease of access in locating profiles and your personal brand will be reinforced.

Step 3. Regularly Engage Creating content regularly will engage followers and keep them coming back to check for new posts and information. Posting daily or multiple times a day is beneficial to maximize traffic to the profile.

Step 4. Content Diversification Changing content type increases the chance of engaging followers in posts. Photos, videos, series, articles, and going live are some of the various types of posts different followers may be inclined to react to.

Step 5. Connect with Influencers. Influencers are industry leaders, thought leaders, authors, or other public figures that inspire others to take action. Engaging influencers by consistently asking questions, posting remarks to photos, or sharing content is a way to be noticed. Once noticed, working toward collaboration on a project or sharing each other's content can be achieved.

Step 6. Volunteer Services. Being genuinely concerned with contacts or followers will reinforce a personal brand by conveying the message that you care. Asking how one's day is going, if they need help with anything, or even wishing a happy birthday can go a long way and keep you in the front of their mind.

Step 7. Provide Questions. Posting questions to followers is a great way to get engagement and create dialogue amongst multiple parties.

Step 8. Contribute to Discussions. On group pages, influencers and follower's pages, contribute to discussions. Doing so will increase the online presence of the personal brand and increase followers, thus, increasing the brand recognition.

Step 9. Monitor. Tools that aid in monitoring a name or brand on social media exist for the sole purpose of keeping individuals connected to name brand and content. Any time an individual uses your brand or name, a notification will appear. Also, keywords can be flagged to notify you when a discussion is happening that may be beneficial to join.

Using social media to build a personal brand can be time-intensive and daunting at times. Social media websites typically incorporate tools that ease the process. Furthermore, online tutorials and applications alleviate some of the stress by showing how to simplify tasks such as posting to multiple platforms with a couple clicks of a mouse. Social media is changing the mode, method, and frequency of brand communications and as organizational leaders, you remain in control of the narrative. 


\section{The Leadership Brand Promise}

As soon as the organizational leader accepts a leadership position, positioning the personal brand becomes central to establishing credibility with organizational followers. The first 100 days in a new position provides multiple opportunities to display and reinforce the brand message and strategy. The manner in which the leader introduces change to the organization puts the brand message at the core of leadership actions. Through the leadership brand, the organizational leader promises integrity of message and actions. Franko (2015) advocates that leadership identity start with your personal brand. It is the promise inherent in the personal brand that fuels leader effectiveness and accomplishments. Franko further explains that your presence in the workplace and the professional world gives evidence of your personal brand. Therefore, the thoughts and ideas you manifest, the consistency of your actions, your professional aptitude, your interactions with followers, and your readiness to take on new challenges make the brand impact statement.

Organizational outcomes improve as leaders gain competence in the personal brand promise and personal brand promotion. Branding behaviors are learned behaviors. Consequently, programs that prepare organizational leaders may consider including the basics of personal brand development in leader preparation curriculum.

\section{Conclusion}

The purpose of this paper was to explore the concept of personal branding as an organizational construct for preparing leaders. Research suggests that branding emerges as an intentional act that leaders incorporate into the development of leadership behaviors and traits. Leaders who create the personal brand take into account the impact on followers and the ability to model organizational strategic objectives.

Personal branding involves self-awareness and the assessment of personal strengths and attributes. Therefore, leadership preparation programs may consider incorporating personal branding strategies and activities into course curricula and program objectives. As Franko (2015) suggests, helping emerging leaders align consistency of actions with thought and ideas is helpful in learning how to develop and implement a personal brand statement.

While branding and marketing are core concepts in business, they are relatively unknown in education. The cross-disciplinary application of these concepts is timely, and both disciplines can benefit from a more robust discussion of utilizing personal branding constructs in the preparation of 21 st-century organizational leaders.

\section{References}

Backstrom, L., Boldi, P., Rosa, M., Ugander, J., \& Vigna, S. (2012). Four degrees of separation. In Proceedings of the 4th Annual ACM Web Science Conference, pp. 33-42, ACM.

Bedburry, S. (2002). A New Brand World: 8 Principles for Achieving Brand Leadership in the 21st Century. New York, NY: The Penguin Group.

Demers, J. (2016). 5 Steps to Building a Personal Brand (and Why You Need One). Retrieved from http://www.inc.com/jayson-demers/5-steps-to-building-a-personal-brand-and-why-you-need-one.html

Erdoğmuş, İ. E., \& Çiçek, M. (2012). The Impact of Social Media Marketing on Brand Loyalty. Procedia - Social and Behavioral Sciences, 58, 1353-1360.

Fournier, S. (1998). Consumers and Their Brands: Developing Relationship Theory in Consumer Research. Journal of Consumer Research, Inc. 24, 343-373. https://doi.org/10.1086/209515

Franko, A. (2015). Building a Leadership Identity Starts with a Personal Brand. Retrieved from https://www.td.org/Publications/Blogs/Human-Capital-Blog/2015/09/Building-a-Leadership-Identity-Starts-wit h-a-Personal-Brand

Hyder, S. (2014). 7 Things you can do to build an awesome personal brand. Retrieved from http://www.forbes.com/sites/shamahyder/2014/08/18/7-things-you-can-do-to-build-an-awesome-personal-brand /\#6562d93e1274

James, L. (2016). The Official Website of Lebron James. Retrieved from http://www.lebronjames.com/

Kapferer, J. N. (2004). The New Strategic Brand Management: Creating and Sustaining Brand Equity Long Term. London, United Kingdom: Les Editions d' Organisation.

Kaputa, C. (2003) Increase Your Visibility: How Smart People Brand Themselves for Business Success. Retrieved from http://www.pharmexec.com/increase-your-visibility-how-smart-people-brand-themselves-business-success 
Labrecque, L. I., Markos, E., \& Milne, G. R. (2011). Online personal branding: process, challenges, and implications. Journal of Interactive Marketing, (25), 27-50

Lake, L. (2016). What is Personal Branding and What You Need to Know about It? Retrieved from https://www.thebalance.com/what-is-personal-branding-4056073

Martinuzzi, B. (2014). How to build an unforgettable personal brand, Retrieved from https://www.americanexpress.com/us/small-business/openforum/articles/how-to-build-an-unforgettable-persona l-brand/

Montoya, P. (2002). The brand called you: The ultimate brand building and business development handbook to transform anyone into an indispensable personal brand. Tennessee: Vaughn Printing.

Northouse, P. G. (2014). Leadership: Theory and Practice (7th ed.). Thousand Oaks, CA: Sage Publications Inc.

Patel, S. (2016). 9 Ways to Use Social Media to Build Your Personal Brand. Retrieved from http://www.forbes.com/sites/sujanpatel/2016/11/12/9-ways-to-use-social-media-to-build-your-personal-brand/2/ \#3c6593547837

Reis, A., \& Reis, L. (2002). The 22 Immutable Laws of Branding: How to Build a Product or Service into a World-Class Brand. New York, NY: Harper Collins.

Saltzman, B. S. (2015). Why personal branding is essential to career success. Retrieved from Fast Company: https://fastcompany.com/3048401/how-to-be-a-success-at-everything/why-personal-brnading-is-essential-to-car eer-success

Smale, T. (2015). 5 Steps to Build Your Personal Brand. Retrieved from https://www.entrepreneur.com/article/250924

Travers, J., \& Milgram, S. (1967). The small world problem. Psychology Today, 1, 61-67.

Williams, D. (2015). Why developing a personal brand is essential for every entrepreneur. Retrieved from http://www.forbes.com/sites/davidkwilliams/2015/06/10/why-developing-a-personal-brand-is-essential-for-ever y-entrepreneur/\#2056070871f4]

Williams, J. (2017). The basics of branding. Retrieved from Entrepreneur: https://www.entrepreneur.com/article/77408 